\title{
In memoriam ...
}

Chirurgia (2016) 111: 461-462

No. 6, November-December

Copyright@ Celsius

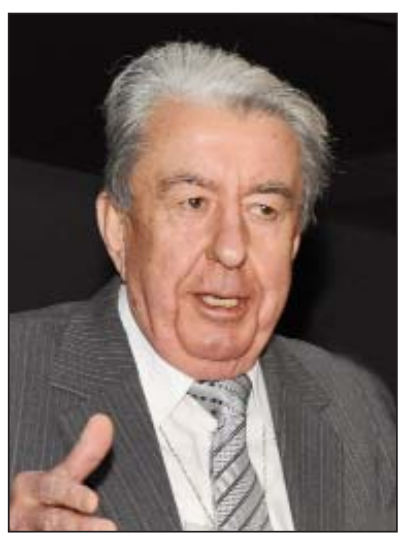

\section{Profesorul Corneliu Dragomirescu}

Profesorul Corneliu Dragomirescu s-a născut la 21 martie 1942 la București.

A absolvit liceul Spiru Haret şi a fost admis la Institutul de Medicină și Farmacie București (Facultatea de Medicină Generală) în 1959, devenind medic în 1965. Din 1967 ị̂i desfășoară activitatea profesională în Clinica de Chirurgie a Spitalului Cantacuzino condusă de Prof. Dr. Ion Juvara, ca medic secundar (1967-1971), medic specialist chirurg (19711978) devenind medic primar în 1978. Sub conducerea profesorului Ion Juvara a elaborat şi susținut teza "Readaptarea după Splenectomie", obținând titlul ştiințific de Doctor în Medicină în anul 1974.

În paralel, parcurge etapele dezvoltării carierei didactice, fiind asistent universitar (1973-1983) şi şef de lucrări (19831986), conferențiar (1986-1993) şi profesor de chirurgie din 1993.

S-a remarcat atât ca un foarte bun operator, cât şi ca un clinician desavârşit, ordonat şi meticulos dar, mai ales, dotat cu o memorie ieşită din comun.

Ca majoritatea elevilor Profesorului Juvara, a fost nelipsit de la Şedintele Societății de Chirurgie Bucureşti, unde a şi prezentat lucrări extrem de documentate, expuse într-o manieră clară şi precisă. Multe dintre ele au fost publicate ulterior în revista "Chirurgia".

Din 1986, a condus Clinica de Chirurgie a Spitalului Vitan Bârzeşti, devenit după 1990 Spitalul Clinic "Sfântul Ioan" Bucureşti.

A fost printre puținii chirurgi români care a ajuns Şef de Clinică la o vârstă tânără, de numai 45 de ani, şi asta exclusiv datorită meritelor sale profesionale.

Creativ, consecvent și profund orientat către progresul medical, profesorul Corneliu Dragomirescu reorganizează clinica de chirurgie a spitalului Sfântul Ioan focalizându-se asupra noilor tehnologii apărute în practica medicală.

Având șansa noilor deschideri de după decembrie 1989, participă, în vara anului 1993, la un program de pregătire pentru revoluționara, la acea vreme, chirurgie laparoscopică.
Perioada petrecută în Marea Britanie, în Clinica de Chirurgie condusă de profesorul Mike McMahon, (University of Leeds), avea să orienteze clar viziunea profesorului Corneliu Dragomirescu asupra viitorului chirurgiei chirurgiei videoasistate.

Întors în țară, cu sprijinul UMF Carol Davila, a introdus tehnica laparoscopică în Clinica de Chirurgie Sfântul Ioan, în ianuarie 1994 fiind realizată prima colecistectomie laparoscopică. Anii care au urmat au fost foarte prolifici din acest punct de vedere, echipa condusă de profesorul Corneliu Dragomirescu introducând tehnica laparoscopică pentru majoritatea operațiilor din sfera chirurgiei generale, ginecologice, urologice, endocrine, de cele mai multe ori ca premiere naționale.

Dezvoltarea tehnicilor laparoscopice adresate diferitelor patologii chirurgicale a fost un obiectiv central pentru profesorul Corneliu Dragomirescu. De la preocuparea continuă de a fi informat despre evoluția tehnicilor videoasistate, participând constant la workshop-uri, cursuri și congrese internaționale, la organizarea de programe de instruire pentru aceste tehnici, de la fondarea societăților profesionale dedicate acestui progres tehnologic până la implicarea în proiecte de cercetare cu această tematică, de la formarea atentă a echipei chirurgicale pe care o coordona până la conferințele și prezentările susținute magistral în cadrul congreselor medicale, activitatea profesorul Corneliu Dragomirescu a contribuit cu prisosință la instituționalizarea chirurgiei laparoscopice în România.

Fiind conștient că realizarea technicilor "prin gaura cheii" impune antrenament susținut, profesorul Corneliu Dragomirescu organizează, încă din 1994 primele cursuri de chirurgie laparoscopică. Expunerile teoretice și demonstrațiile operatorii se realizau în Clinica de Chirurgie a Spitalului Sfântul Ioan în timp ce, activitatea practică, folosind modelul suin, la Facultatea de Medicină Veterinară. Suportul tehnic și spijinul logistic a fost oferit de Olympus Winter Ibe până în 2001 și apoi, de echipa entuziastă Karl STORZ, alături de care 
activitatea de training în chirurgie endoscopică s-a dezvoltat fără precedent. Colaborarea ireproșabilă cu echipa de medici veterinari, cu profesorul Ion Miclăuș, conducătorul Clinicii de Chirurgie, în mod special, a facilitat continuarea acestor cursuri, în acest cadru, pentru următori 15 ani. Dacă inițial, antrenamentul pe model suin se realiza la două posturi de lucru, utilizând anestezie intravenoasă, organizându-se 1-2 cursuri pe an universitar, in 2010, erau organizate 6 cursuri pe an, folosind șase posturi de lucru și anestezie generală cu intubație orotraheală.

Din 2011, profesorul Corneliu Dragomirescu a coordonat activitatea științifică în Centrul de Training în Chirurgie Laparoscopică PONDERAS Hospital, implicându-se, cu multă dedicație în desfășurarea fiecărui curs, numărul anual al acestor activități extinzându-se la douăspezece. Participanții la aceste cursuri, chirurgi de chirurgie generală, pediatrică sau toracică, ginecologi, urologi sau gastroeneterologi au beneficiat de disponibilitatea nelimitată a profesorului Corneliu Dragomirescu, de generozitatea greu de egalat cu care transfera din experiența acumulată celor care se aflau în diferite etape ale curbei de învățare.

În paralel, profesorul Corneliu Dragomirescu desfășoară o susținut activitate publicistică și de cercetare. Numim două dintre proiectele de cercetare derulate cu succes in anii ' 90 : Optimizarea tratamentului defectelor parietale prin chirurgie laparoscopică cu utilizarea de plase colagenate (Academia Română, 1997-1998) și Cercetări privind realizarea de echipamente opticomecanice, optoelectronice și mecanice destinate investigării și chirurgiei miniinvazive aplicate la organele umane din cavitatea toracică și abdominală (Ministerul cercetării, 1999-2000).

În 1996, profesorul Corneliu Dragomirescu semnează ca editor și coautor monografia Chirurgie laparoscopică. Actualități şi perspective (Editura Tehnică, București), care, alături de ediția digitală intervactivă "Atlas of Laparoscopic Surgery" - (CD-ROM. Editura Celsius, București) au cuprins informații esențiale pentru dezvoltarea chirurgiei videoasistate în România. Succesul acestor lucrări dar, mai ales dezvoltarea rapidă a tehnicilor asistate avansate, au fost premizele realizării unui alt proiect foarte important: „Chirurgia Miniinvazivă Tehnici Avansate" o serie de 8 CD-ROM-uri lansate in 2000, profesorul Corneliu Dragomirescu fiind co-editor alături de profesorul Irinel Popescu. Importanța educațională a acestei realizări a fost imediat remarcată fiind distinsă, cu premiul "Iuliu Hațieganu" al Academiei Române, în Decembrie 2000.

Influența profesorului Corneliu Dragomirescu asupra evoluției chirurgiei miniminvazive în România este marcată și de implicarea domniei sale în elaborarea curiculei de pregătire pentru chirurgie laparoscopică, fiind, începând cu 2003, coordonator al Programului Național de instruire în Chirurgia Laparoscopică.
Membru al numeroase asociațiilor profesionale: Societatea Română de Chirurgie Laparoscopică şi Suturi Mecanice, Societatea Română de Chirurgie, European Association of Endoscopic Surgery, European Digestive Surgery, International Society of Surgery, International Association of Surgeons and Gastroenterologists, profesorul Corneliu Dragomirescu a fost inițiator, membru fondator, primul Președinte și Preşedinte de onoare al Asociației Române de Chirurgie Endoscopică (ARCE), for dinamic de promovare și dezvoltare a tehnicilor videoasistate de diagnostic și tratament în România.

Profesorul Dragomirescu s-a făcut cunoscut în circuitele științifice internaționale, stabilind inițial o foarte bună colaborare cu Profesorul Gerd Lepsien din Germania și, mai apoi, o lungă și stabilă relație cu Profesorul Jacques Marescaux și școala lui de la Strasbourg.

A comunicat și publicat încă de la începutul anilor ' 90 , primele rezultate în diverse tipuri de operații laparoscopice, multe dintre ele constituind premiere naționale. Le regăsim pe toate într-un articol de sinteză asupra istoriei chirurgiei laparoscopice în România, publicat peste ani: C. Dragomirescu, C. Copăescu "Repere istorice publicistice privind chirurgială paroscopică în România. Lucrări apărute în revista Chirurgia" (Chirurgia; 2010;105(5):603-24).

Pedagog înăscut, medic talentat și profesor erudit, profesorul Corneliu Dragomirescu a fost prorector al U.M.F. "Carol Davila" Bucureşti în perioada 1992-2004.

Profesorul Dragomirescu a format o scoală de chirurgie care, asa cum era de asteptat, a fost orientată mai ales către chirurgia miniinvazivă.

Eleviilui se numara in prezentprintreceimaibunichirurgilaparoscopisti din Bucurestisi din tara.

Ca urmare a recunoaşterii valorii activității profesionale și de cercetare depuse, în 1993 profesorul Corneliu Dragomirescu a devenit membru al Academiei de Ştiințe Medicale, iar in Noiembrie 2002, in semn de apreciere a contribuției domniei sale la dezvoltarea medicinii romanești, a fost distins cu ordinul Ordinul Național "Steaua României” în gradul de Cavaler.

Întreaga comunitate medicală din România au pierdut unul dintre cei mai de seamă chirurgi pe care i-a avut țara noastră. Personalitatea, forța și profesionalismul domnului profesor Corneliu Dragomirescu au marcat puternic destinele noastre în chirurgia din România.

Zecile de mii de pacienți, cei peste două mii de medici din toate specialitățile chirurgicale care au fost instruiți în cursurile de training coordonate de domnul profesor Corneliu Dragomirescu în ultimii 20 de ani și contribuția domniei sale la dezvoltarea chirurgie laparoscopice sunt mărturii incontestabile pentru valorile umane, profesionale și pedagogice ale unei personalităti remarcabile. Vă vom păstra o neștearsă amintire, domnule profesor! 